„Kwartalnik Filmowy” nr 113 (2021)

ISSN: 0452-9502 (Print) ISSN: 2719-2725 (Online)

https://doi.org/10.36744/kf.753

(c) Creative Commons BY-NC-ND 4.0

\title{
Urszula Makowska
}

Instytut Sztuki, Polska Akademia Nauk

https://orcid.org/0000-0002-3732-5680

\section{Najintensywniej i najswobodniej być}

\author{
Slowa kluczowe: \\ Wiesław Juszczak
}

\author{
Abstrakt \\ Wspomnienie o Profesorze Wiesławie Juszczaku \\ (1932-2021).
}

18 lutego 2021 r. zmarł Profesor Wiesław Juszczak, jeden z najbardziej niezwykłych ludzi, jakich dane mi było poznać - piękny, mądry, niezależny.

Po ukończeniu historii sztuki na Uniwersytecie Warszawskim od 1961 r. pracował do końca życia w Instytucie Sztuki Polskiej Akademii Nauk. Przez ponad dwadzieścia lat prowadził także zajęcia na swojej macierzystej uczelni, a przez jakiś czas współpracował z Katolickim Uniwersytetem Lubelskim. Wypromował kilkudziesięciu doktorów. Prace, które powstawały na Jego seminarium, dotyczyły malarstwa, rzeźby, grafiki, a także filmu, fotografii, teatru, antropologii, filozofii i literatury, słowem - sposobów istnienia sztuki. Profesor nie stawiał granic między poszczególnymi dyscyplinami, traktując je jako rozmaite przejawy twórczości. Sam był wybitnym znawcą $\mathrm{w}$ wielu dziedzinach, także tych, którym nie poświęcił osobnych publikacji, jak opera, balet czy muzyka.

Jego dorobek naukowy i literacki (czy może naukowo-literacki) jest jednak i tak bardzo różnorodny i bogaty. Zaczął od artykułu o średniowiecznym tryptyku bodzentyńskim, któremu poświęcił pracę magisterską. Później opublikował serię prac o sztuce XIX i początkach XX w., z których przekrojowe ujęcia postimpresjo- 
nizmu i malarstwa polskiego modernizmu, podobnie jak antologia tekstów o malarzach z lat 1890-1918, służą kolejnym pokoleniom studentów historii sztuki, dziś już pewnie nieświadomych rewolucyjności tezy o współbrzmieniu ekspresjonizmu z nurtem symbolistycznym. Nie straciły również aktualności monografie Grottgera, Chełmońskiego, Wojtkiewicza i „młodego” Weissa, poparte sumiennymi badaniami źródłowymi, ale prezentujące oryginalne interpretacje, w których naukowy dyskurs przechodzi niekiedy w rytm prozy poetyckiej. Indywidualny język i sposób prowadzenia narracji stanowią zresztą sygnaturę pisarstwa Wiesława Juszczaka.

Kontynuację refleksji nad polskim modernizmem zawierają teksty w końcowej części zbioru Fakty i wyobraźnia, w którym znalazły się również eseje będące oddźwiękiem pobytu stypendialnego w Courtauld Institute of Art w Londynie w latach 1962-1963. Wyjazd, połączony z wojażami po Szkocji, zapoczątkował zainteresowanie Profesora kulturą angielską - oprócz prac pomieszczonych we wspomnianym tomie o Robercie Adamie i Williamie Blake’u przełożył utwory tego ostatniego (Milton oraz Zaślubiny Nieba i Piekła), a teoretyczno-literackie rozważania wynikłe z lektury Pani Dalloway Virginii Woolf zawarł w książce Zasłona w rajskie ptaki. O granicach okresu powieści. Później przyszło jeszcze zauroczenie twórczością J. R. R. Tolkiena zakorzenioną w staroangielskich eposach i obrazujących ideę praświata.

Zawsze wyobrażałam sobie, że podczas tego brytyjskiego roku uformował się również (czy raczej utwierdził) ów rozpoznawalny i niemożliwy do podrobienia styl Wiesława Juszczaka, objawiający się w dyskretnej wytworności stroju, nobliwej gestykulacji, w sposobie bycia, łączącym powściągliwość z poczuciem humoru i z życzliwością. Chociaż nie ukrywał swoich antypatii, to kierował je raczej ku słowom, czynom, sprawom czy rzeczom niż ku ludziom. Nie znosił zarówno ordynarności, jak i poloru maskującego banał.

Tłumaczenie dzieł Blake’a zapoczątkowało Jego prace translatorskie. Przekładał inne utwory literatury pięknej - Thomasa S. Eliota, Tennessee Williamsa, anglojęzyczne opowiadania Karen Blixen, jak również prace naukowe-Neoklasycyzm Hugh Honoura, Realizm Lindy Nochlin, Eurypides i jego wiek Gilberta Murraya czy Pierwiastki indyjskie w myśli Słowackiego Maryli Falk. Ten ostatni przekład, opatrzony sporym posłowiem tłumacza, ma związek z rozumieniem literatury jako następstwa (i zastępstwa) praktyk religijnych, nad czym Profesor rozmyślał od jakiegoś czasu. Nie sposób jednak także nie widzieć w tej pracy refleksów fascynacji Królem-Duchem, odczytywanym odkrywczo przez Juszczaka już w latach siedemdziesiątych, w kontekście malarstwa w ogóle i w kontekście polskiego modernizmu.

Stopniowe odchodzenie od historii sztuki ku religii greckiej, historii religii i ku problemowi mitu również miało zaczepienie we wcześniejszych faktach. Prapoczątkiem była może lektura Odysei, którą jako dziecko pochłaniał ukryty w piwnicy podczas nalotów i którą traktował jako dodatkowy schron ${ }^{1}$. (Podobnym refugium, chroniącym przed rzeczywistością uszarganą przez trywialność i interes, była również sztuka, a właściwie tkwiąca w niej energia duchowa twórczości - podobna doświadczeniu religijnemu lub wręcz z nim tożsama). Później doszły kolejne klasyczne lektury, antyk osiemnastowiecznych Anglików i marmury Elgina z British Museum, wreszcie, w końcu lat siedemdziesiątych, nauka greki, spożytkowana w organizowanych z przyjaciółmi próbach Bachantek Eurypidesa. A potem wszystko nabrało wymiaru antropologicznego, śródziemnomorskie po- 
dróże ożywiły wyobrażenia, zaczęły powstawać artykuły i książki składające się na wielowątkowe, ale spójne dzieło o tajemnicy źródeł twórczości - dylogia o Persefonie Pani na żurawiach (część I Realność bogów, 2002, część II Archeologia mitu, 2012), Ekfraza poetycka w antycznej Grecji (2012), Poeta i mit (2014).

Profesor uczył, że sztuka, będąc świadectwem istnienia religii, prowadzi ku granicom między poznawalnym a niepojętym, że po to istnieje i jest jedna, niezmienna w swej istocie, niezależnie od czasu, w którym powstała, i języka, jakim przemawia. A właściwie - jakim zdarza się jej do nas niekiedy przemówić, objawić swoją naturę w epifanicznym błysku. By go doświadczyć, trzeba odrzucić bagaż naukowości i najintensywniej, ale i najswobodniej by ${ }^{2}$. W jednym ze swoich najpiękniejszych esejów Juszczak przestrzegał przed utraceniem tej szansy, gdy w kontakcie z czymś porywajacym kryjemy się za pozorami erudycji, rygorów wiedzy, wszystko próbując poddać racjonalnej wiwisekcji. Dlaczego się bronimy? Przed czym? Czyżbyśmy, wołani przez to wielkie, aż tak się bali? Czego? Może łez? ${ }^{3}$

Sam się nie bał, a Jego ogromna wiedza i niepospolite dyspozycje mentalne były zawsze na usługach tego, co głęboko przeżyte. W bezcennych „rozmowach o twórczości”, jakie Dariusz Czaja prowadził z Profesorem, czytamy między innymi o Jego niechęci (deklarowanej zresztą wielokrotnie) do brutalnego, jak to określił, słowa "odbiór", fałszującego i dewaluującego sposób obcowania ze sztuką ${ }^{4}$. Tymczasem polega on na uczestnictwie, przeżyciu. Wiesław Juszczak sprawdzał to konsekwentnie całym soba, oddając się we władanie sztuki, wstępując w jej łożysko aż do doznania jedności. Kolejne powroty do ulubionego dzieła, kilkakrotne oglądanie tego samego spektaklu teatralnego, siedemnaście seansów jednego filmu Bergmana - to jeden rodzaj praktyk. Przykładem drugiego może być tydzień spędzony samotnie w Eleusis, gdzie właściwie nie było nic, co dałoby się zbadać szkiełkiem i okiem, jedynie trochę kamieni, milczenie wielu tysięcy ust zamkniętych złotym kluczem ${ }^{5}$ i zawieszona nad miejscem tajemnica, którą zdolne są odczuć tylko bardzo czułe (w obu znaczeniach słowa) receptory... Dopiero takie doświadczenia Juszczak poddawał dyscyplinie intelektualnej i władzy giętkiego pióra. Dlatego wierzymy Jego tekstom.

Dla mnie były one zawsze, i są dotąd, źródłem niesłabnącej inspiracji, właściwie niezależnie od tego, o czym traktują. Olśniewają zaskakującymi skojarzeniami i nieoczywistymi spostrzeżeniami, a zapis żywego tętna myśli pobudza i mobilizuje czytelnika. Podobnie uskrzydlały rozmowy z Profesorem i uczestnictwo w dyskusjach na prowadzonym przez Niego seminarium. Trudno jednak ująć krótko to wszystko, co Mu zawdzięczam. Musiałabym mówić nie tylko o sztuce, ale również o zwyczajach mysikrólików czy o szalu w kolorze pervenche. Zresztą nie wszystko zapamiętałam, ale i to, co kapryśna Mnemosyne zechciała ocalić, ma dla mnie wielką wartość. Na przykład spośród wielu seansów filmowych, które Wiesław Juszczak urządzał dla swoich doktorantów, zostały mi w pamięci, nie wiedzieć czemu, tylko dwa - Elizo, życie moje Saury, film wyświetlany w sali kinowej działającej kiedyś w podziemiach Instytutu Sztuki PAN, i Medea Pasoliniego pokazywana w Filmotece przy Puławskiej. Oba filmy oglądane później, już w innych okolicznościach, wydały mi się różne od tamtych, pierwszy raz widzianych i jakby naznaczonych dodatkową niezwykłością.

Jest jeszcze trzeci film. Profesor go lubił, ale kojarzy mi się z Nim nie tylko dlatego. Juszczak pojmował arcydzieło jako obraz "zbliżania się" do Formy, czyli 
ideału tworzenia. Wartości najwyższej, a nigdy do końca nieosiagalnej; ; jako docieranie do granic zmysłowości. Toteż nic dziwnego, że w balecie, śpiewie czy pianistyce podziwiał to, co zdawało się przerastać ludzkie możliwości $i^{7}$. Tę miarę przykładał do wszystkich przejawów twórczości lub - szerzej - ludzkich dążeń. W alpinizmie pociągała go moc wzlotu ku granicom nieosiagalnego ${ }^{8}$. Wyznał również, że sam pisze dlatego, aby się czegoś nauczyć, ale jest w tym też potrzeba zmierzenia się z czymś możliwie najtrudniejszym ${ }^{9}$.

Chyba więc już łatwo zgadnąć, że tym trzecim filmem jest Fitzcarraldo. Werner Herzog na pewno dedykowałby go Wiesławowi Juszczakowi, gdyby Go znał. Oczywiście nie chodzi tu o fizyczne podobieństwo do Klausa Kinskiego, który gra tytułowego wizjonera. Zresztą $\mathrm{w}$ finałowej scenie filmu $-\mathrm{z}$ bohaterem stojącym samotnie na pokładzie płynącego parowca, zachwyconym wystawioną właśnie operą Purytanie - zawsze widzę nie Kinskiego, lecz szczupłego pana w szarym garniturze, który nie pali cygara, jak tamten, tylko długiego papierosa $\mathrm{z}$ ustnikiem. Reszta - dyrygent z orkiestra, soliści i chór, opera (koniecznie Belliniego!) i nawet jeden z czerwonych pluszowych foteli, jakie sa w teatrze ${ }^{10}$ - pozostaje ta sama.

Kiedy przed kilkoma dniami znów obejrzałam Fitzcarralda, nie miałam wątpliwości co do zamiany ról. To Profesor kładzie swoją kruchą dłoń na oparciu czerwonego fotela, unosi głowę, wsłuchany w duet Elviry i Artura, a statek powoli dryfuje w ogromniejący, coraz bardziej niebieski błękit.

${ }^{1}$ W. Juszczak, Lekcja pisania [tekst wygłoszony w PEN Clubie z okazji przyznania Nagrody im. Ksawerego i Mieczysława Pruszyńskich w 2010 r.], „,Konteksty” 2010, nr 2-3, s. 14.

2 Tenże, Notatnik z Malty, w: tegoż, Wędrówka do źródet, słowo/obraz terytoria, Gdańsk 2009, s. 240.

3 Tenże, "Nic watlejszego nad krzemień $i$ diament...", w: Twarza w twarz z obrazem, red. M. Poprzęcka, Stowarzyszenie Historyków Sztuki, Warszawa 2003, s. 16 (przedruk w: tegoż, Wędrówka do źródet, dz. cyt.).

${ }^{4}$ D. Czaja, W. Juszczak, Ruiny czasu. Rozmowy o twórczości, Wydawnictwo Czarne, Wołowiec 2017, s. 142.
${ }^{5}$ W. Juszczak, Dziennik apokryficzny, w: tegoż, Pani na żurawiach. Czesść pierwsza: Realność bogów, Aureus, Kraków 2002, s. 27 (przedruk w: tegoż, Wędrówka do źródet, dz. cyt.).

${ }^{6}$ D. Czaja, W. Juszczak, dz. cyt., s. 273.

7 Tamże, s. 161.

8 Tamże, s. 70.

9 Tamże, s. 209.

${ }^{10}$ Fitzcarraldo (reż. Werner Herzog, 1982); cytat wg polskiej listy dialogowej Marii Etienne, 2:24:55.
Urszula Makowska
Historyczka sztuki. Pracuje w zespole autorsko-redakcyjnym Stownika artystów polskich i obcych w Polsce działajacych... w Instytucie Sztuki Polskiej Akademii Nauk; od 1994 r. współpracuje jako autor haseł z Allgemeines Künstlerlexikon. Zajmuje się sztuką polską XIX i pierwszej połowy XX w., kierując uwagę zwłaszcza na jej relacje z literaturą. Publikuje artykuły o twórczości rysunkowej pisarzy i wizualnej interpretacji utworów literackich, głównie Juliusza Słowackiego, w tomach pokonferencyjnych i czasopismach („Konteksty”, 
„Teksty Drugie”, „Ikonotheka”, „Pamiętnik Sztuk Pięknych”, „Schulz / Forum”). Interesuje się także związkami sztuki $\mathrm{z}$ innymi dziedzinami (medycyna, folklor, teatr) oraz kulturą popularną jako obszarem recepcji wielkich dzieł (malarstwo, literatura, muzyka).

\title{
Bibliografia
}

Czaja, D., Juszczak, W. (2017). Ruiny czasu. Rozmowy o twórczości. Wołowiec: Wydawnictwo Czarne.

Juszczak, W. (2002). Pani na żurawiach. Czesść pierwsza: Realność bogów. Kraków: Wydawnictwo Aureus.

Juszczak, W. (2003). „Nic wątlejszego nad krzemień i diament...”. W: M. Poprzęcka (red.), Twarza w twarz z obrazem (ss. 9-17). Warszawa: Stowarzyszenie Historyków Sztuki.

Juszczak, W. (2009). Notatnik z Malty. W: W. Juszczak, Wędrówka do źródeł (ss. 231-243). Gdańsk: słowo/obraz terytoria.

Juszczak, W. (2010). Lekcja pisania [tekst wygłoszony w PEN Clubie z okazji przyznania Nagrody im. Ksawerego i Mieczysława Pruszyńskich w 2010 r.]. Konteksty, 289$-290(2-3)$, SS. $14-15$.

\author{
Keywords: \\ Abstract \\ Wiesław Juszczak \\ Urszula Makowska \\ To Just Be, Most Intensively and Freely \\ A Memory of Professor Wiesław Juszczak (1932-2021).
}




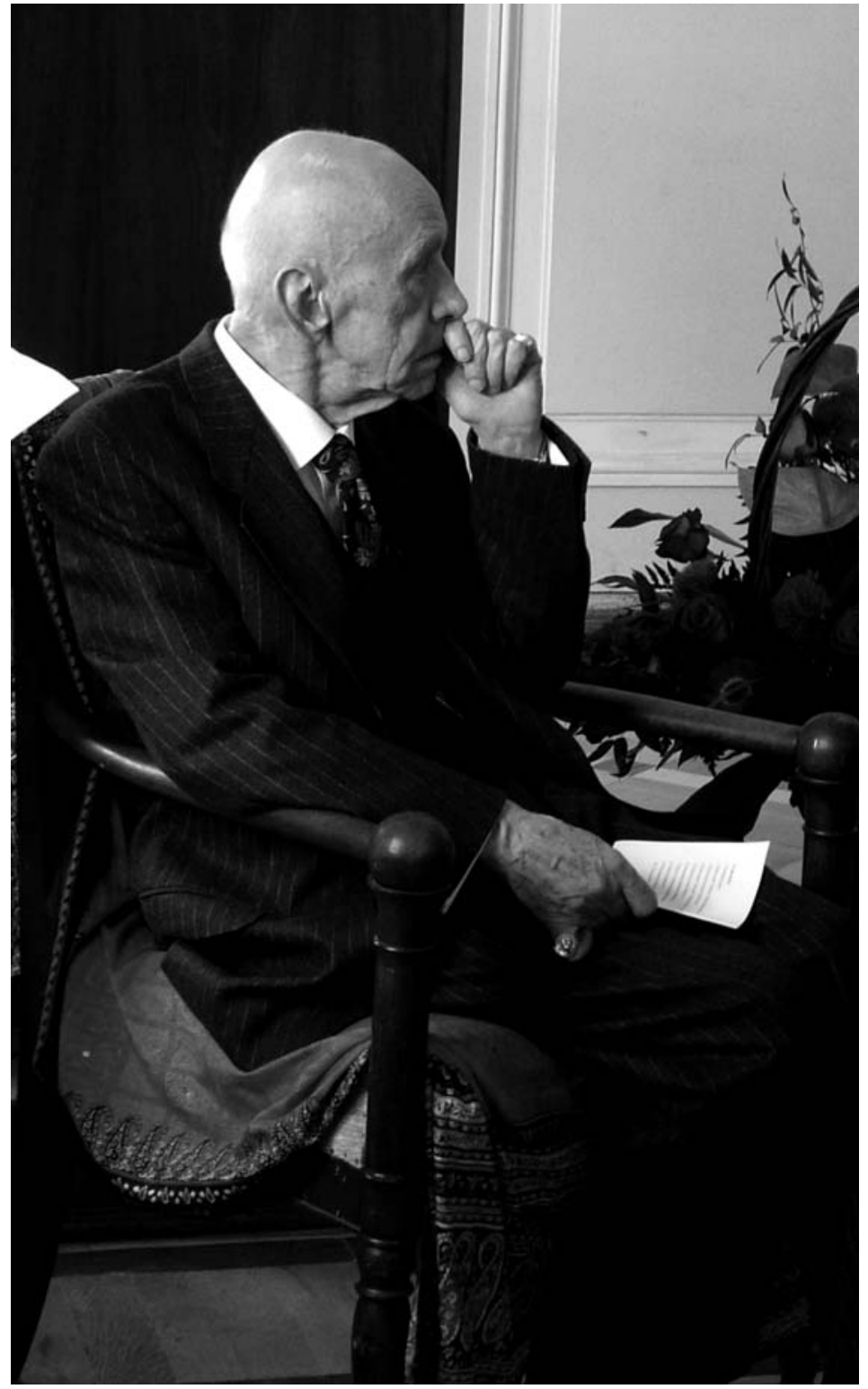

